\title{
Impact of Collared Dove Pigeons (Streptopelia decaocto) Age on some Hematological and Biochemical Parameters in Mosul City
}

\author{
Sinan Th. Abdullah \\ Department of Basic Science/ College of Dentistry/ University of Mosul
}

E-mail: dr. sinantag 78@ gmail.com

(Received 29/1/2019; Accepted 30/7/2019)

\begin{abstract}
The study conducted to determine the effect of differences of age on hematological and biochemical values of collared dove pigeons (Streptopelia decaocto) in Mosul city, Iraq. 28 healthy collared dove of 4 different age groups (7 birds of each group) 1 month, 3month, 6 months old as immature and 12 months old as mature pigeons were collected from local areas of Mosul city during May to August 2018. Total red blood cells (TES), packed cell volume (PCV), hemoglobin concentration $(\mathrm{Hb})$, differential of white blood cells, serum total protein, cholesterol, triglycerides, uric acid and glucose were determined. The results showed fluctuations in parameters with different age groups. Mature birds had a significant increase $(\mathrm{P} \leq 0.05)$ in $\mathrm{PCV}, \mathrm{Hb}$, Basophils, Monocytes, Lymphocytes, total protein and uric acid compared to immature birds. In the mature birds, there was a decrease in both heterophils, $\mathrm{H} / \mathrm{L}$ ratio, total cholesterol, triglycerides and glucose when compared to immature birds. The conclusion from this study there is differences in blood parameters in collared dove pigeons according to the age advanced.
\end{abstract}

Keywords: collared dove, Haematological parameters, immature, mature pigeons.

\section{تأثير عمر الحمام الفاخت في بعض الصفات الدموية والكيموحيوية في مدينة الموصل}

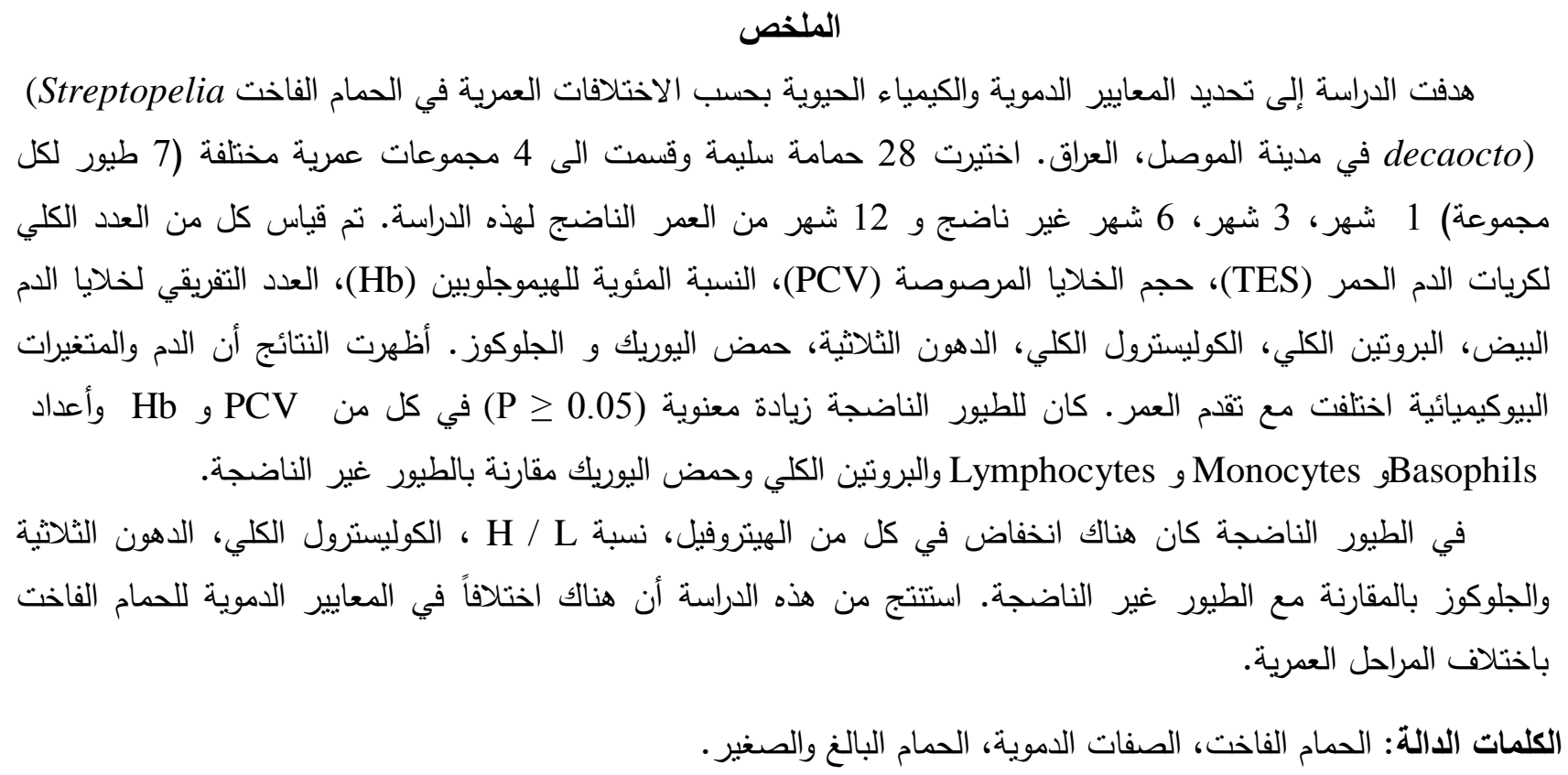




\section{INTRODUCTION}

The collared dove pigeons are a bird species that has the ability to adapt and live in different parts of the world where the construction of nests on different and high areas (Moudhafer et al., 2006). The examination of blood and serology of local birds provides diagnostic information to detect the state of health and natural knowledge of the conditions that can cause a change in these values (Hauptmanova et al., 2002). Hematological parameters are used extensively in avian medicine and provide valuable information on the immune status (Kral and Suchy, 2000). Hematological value of healthy birds are affected by factors including physiological and environmental conditions, age, fasting and dietary content (Seiser et al., 2000). The measurement of blood standards in local conditions is very important in the management, prevention and treatment of diseases at the level of individual or herd (Lashev et al., 2009; Tras et al., 2000). The biochemical parameters could be an important source of information with valuable diagnostic meaning in both domestic and wild birds (Miller et al., 2001). Clinical blood chemistry is useful diagnostic tools and has motivated the publication of a large number of scientific reports in various free living or captured avian species (Palvak et al., 2005). Blood biochemistry from serum samples may provide necessary information for evaluation of health status of pigeons and reflect the metabolic alterations of all types of organs and tissues (Schalm et al., 1975). Plasma protein consists of hundreds of proteins with a wide range of functions and structures including nutrition, maintenance of osmotic pressure, buffering, transport of small ions and molecules, haemostasis and protective effect of the immune proteins (Harr, 2002a). Uric acid is the primary catabolic production of protein and non protein nitrogen in birds, it is synthesized in the kidneys and liver of fowl and it is excreted by the kidney by filtration and tubular secretion(Hames and Hooper, 2002). Glucose is the source of energy that is transported in the plasma delivered to all cells of the body (Chandler et al., 1979). The lipid profile concentration of triglycerides, total cholesterol, HDL and LDL lipoprotein fractions in blood serum are the main caloric reserve in the organism (Kasprzak and Hetmanski, 2004). Cholesterol is an important constituent of cell membranes modulating their fluidity; it is also a precursor of steroid hormones (Hames and Hooper, 2002).

The current study was conducted to investigate the age effect on some blood parameters in the collared dove model under the conditions of the city of Mosul, because it is necessary to know it to assess the nutritional status and monitor health and disease (Payne et al., 1970).

\section{Experimental birds}

\section{MATERIALS AND METHODS}

28 Collared Dove pigeons (both sexes) were used in the research and tested at age of (1 month, 3 months, 6 months old as immature and 12 months old as mature pigeons (Fransson et al., 2010). Collared Dove (Streptopelia decaocto) was collected from market in Mosul, Iraq in august 2018 and had free access to feed and water (ad libitum). The suitable environmental conditions like temperature, lighting (continues), ventilation, well humidity percentage were recorded daily throughout experiment period (dry temperature $28.07 \pm 0.29{ }^{\circ} \mathrm{C}$, wet temperature $25.90 \pm 0.30{ }^{\circ} \mathrm{C}$ and relative humidity of $\left.82.15 \pm 2.01 \%\right)(17)$. During experimental period a photoperiod of $14 \mathrm{~L}$ : $10 \mathrm{D}$ was performed, all the conditions are recommended by NRC (NRC, 1984).

\section{Sample of blood}

The blood samples were collected from fasted birds overnight from jugular vein using capillary (heparinzed) tubes. During two hours of blood collection, the hematological studies were performed in same time of all groups. Total erythrocyte count (TEC), white blood cell count (WBC) were obtained with haemocytometer method. The different types of WBC counts were determined on blood smears by use of (Wright-Giemsa) stain (shen and Patterson, 1983). Packed cell volume 
$(\mathrm{PVC} \%)$ and Hemoglobin $(\mathrm{Hb})$ concentration $(\mathrm{g} / \mathrm{dl})$ were determined by microhaematocrit and sahli haemometer methods respectively.

Serum protein, total cholesterol, triglycerides, uric acid and glucose were performed by Reflotron plus 2011 (Roche, Germany) (Grunenberg et al., 1995).

\section{Statistical analysis}

Analyses of data were performed using analysis of variance ANOVA test by SPSS software program package (version 17). Also, significant differences among means \pm S.E. between groups at $\mathrm{P} \leq 0.05$ were determined by Duncan's multiple range test (Steel and Torrie, 1980).

\section{RESULTS AND DISCUSSION}

Table (1) showed that the TEC, PCV and Hb were significantly $(\mathrm{P} \leq 0.05)$ decreased in immature pigeons compared to the mature. However, TEC, PCV and Hb values increased with the advancement of age, being lowest in the immature and highest in the mature pigeons. These results agree with (Schmidt et al., 2007; Islam et al., 2004), who mentioned that the TEC, PCV and Hb are increased in the advanced aged chicken. The increases of these values with the differences of ages may be due to the greater oxygen demand for activity. The significantly decrease in TEC, values of $\mathrm{PCV}$ and $\mathrm{Hb}$ in immature birds compared to the mature may be due to the normal lower of iron concentration in immature birds causing physiological anemia, and the increase of TEC, PCV and $\mathrm{Hb}$ values in the mature pigeons are consistent with their greater flight ability (Gayathri and Hegde, 1994). The TEC, PCV and hemoglobin values are affecting by changes in the important factors like temperature and photoperiod (Rewkiewiccz-Dziarska, 1975).

Table 1: Effect of age on some hematological parameters of Collared Dove pigeons (Streptopelia decaocto).

\begin{tabular}{|c|c|c|c|c|}
\hline \multirow{2}{*}{ Parameters } & \multicolumn{4}{|c|}{ Ages } \\
\cline { 2 - 5 } & 1 month & 3 months & 6 months & 12 months \\
\hline TEC (10 $\left.\mathbf{6} / \mathbf{m m}^{\mathbf{3}}\right)$ & $1.77 \pm 0.01 \mathrm{c}$ & $1.99 \pm 0.54 \mathrm{c}$ & $2.89 \pm 0.32 \mathrm{~b}$ & $4.89 \pm 1.18 \mathrm{a}$ \\
& & & & \\
\hline Hb $(\mathbf{g} / \mathbf{d l})$ & $2.66 \pm 0.23 \mathrm{~d}$ & $4.22 \pm 1.45 \mathrm{c}$ & $7.59 \pm 1.76 \mathrm{~b}$ & $12.45 \pm 1.18 \mathrm{a}$ \\
\hline PCV (\%) & $9.99 \pm 1.25 \mathrm{~d}$ & $15.65 \pm 0.77 \mathrm{c}$ & $26.76 \pm 1.65 \mathrm{~b}$ & $39.34 \pm 0.18 \mathrm{a}$ \\
\hline
\end{tabular}

Values represent Mean \pm S.E.

\section{Different letters in each row mean significant differences $(\mathbf{p} \leq \mathbf{0 . 0 5})$.}

Table (2) showed that the blood Eosinophils, Heterophils and H/L ratio values were significantly $(\mathrm{P} \leq 0.05)$ higher in immature pigeons compared to mature. The count of monocytes and basophiles were significantly $(\mathrm{P} \leq 0.05)$ increased with advancing of age but a heterophils and $\mathrm{H} / \mathrm{L}$ ratio were significantly $(\mathrm{P} \leq 0.05)$ decreased. These results are in agreement with (Pavlac et al., 2005), who found that differential leukocytes in immature pigeons showed a smaller percentage of lymphocytes $(\mathrm{P} \leq 0.05)$ than that found in the mature. The smaller the age, the lower the proportion of lymphocytes (Harr, $2002 \mathrm{~b}$ ). In addition, the differences in the lymphocytes (\%) may be attributed to the difference between the ages. 
Table 2: Effect of age on leukocytes parameters of Collared Dove pigeons (Streptopelia decaocto)

\begin{tabular}{|c|r|r|r|r|}
\hline \multirow{2}{*}{ Parameters } & \multicolumn{4}{|c|}{ Ages } \\
\cline { 2 - 5 } & 1 month & 3 months & 6 months & 12 months \\
\hline TLC(10 $/ \mathbf{m m}^{\mathbf{3}}$ ) & $7.89 \pm 1.45 \mathrm{~d}$ & $12.90 \pm 0.65 \mathrm{c}$ & $20.43 \pm 1.69 \mathrm{~b}$ & $26.50 \pm 0.54 \mathrm{a}$ \\
\hline Heterophil (\%) & $47.49 \pm 0.50 \mathrm{a}$ & $41.65 \pm 1.67 \mathrm{~b}$ & $35.11 \pm 0.23 \mathrm{c}$ & $31.55 \pm 2.54 \mathrm{~d}$ \\
\hline Eosinophil (\%) & $4.43 \pm 1.50 \mathrm{a}$ & $3.96 \pm 0.15 \mathrm{~b}$ & $2.86 \pm 1.65 \mathrm{c}$ & $1.98 \pm 1.10 \mathrm{~d}$ \\
\hline Basophil (\%) & $0.33 \pm 1.52 \mathrm{~d}$ & $0.89 \pm 1.43 \mathrm{c}$ & $1.22 \pm 1.20 \mathrm{~b}$ & $2.15 \pm 0.10 \mathrm{a}$ \\
\hline Lymphocyte (\%) & $12.39 \pm 0.44 \mathrm{~d}$ & $22.49 \pm 0.23 \mathrm{c}$ & $37.86 \pm 0.34 \mathrm{~b}$ & $47.43 \pm 0.86 \mathrm{a}$ \\
\hline Monocyte (\%) & $0.29 \pm 1.43 \mathrm{~d}$ & $0.77 \pm 0.82 \mathrm{c}$ & $1.10 \pm 0.28 \mathrm{~b}$ & $1.96 \pm 0.54 \mathrm{a}$ \\
\hline H/L ratio & $3.83 \pm 2.92 \mathrm{a}$ & $1.84 \pm 0.85 \mathrm{~b}$ & $0.92 \pm 0.73 \mathrm{c}$ & $0.66 \pm 0.51 \mathrm{~d}$ \\
\hline
\end{tabular}

Values represent Mean \pm S.E.

Different letters in each row mean significant differences $(\mathrm{p} \leq 0.05)$.

Table 3: Effect of age on biochemical parameters of Collared Dove pigeons (Streptopelia decaocto)

\begin{tabular}{|c|c|c|c|c|}
\hline \multirow{2}{*}{ Parameters } & \multicolumn{4}{|c|}{ Ages } \\
\cline { 2 - 5 } & $\mathbf{1}$ month & 3 months & 6 months & 12months \\
\hline Total protein (g/dl) & $1.97 \pm 3.03 \mathrm{~d}$ & $2.11 \pm 7.06 \mathrm{c}$ & $2.24 \pm 1.32 \mathrm{~b}$ & $2.45 \pm 4.67 \mathrm{a}$ \\
\hline Total cholesterol (mg/dl) & $80.70 \pm 1.49 \mathrm{a}$ & $89.21 \pm 0.32 \mathrm{a}$ & $86.33 \pm 2.89 \mathrm{a}$ & $64.67 \pm 1.21 \mathrm{~b}$ \\
\hline Triglycerides (mg/dl) & $112.43 \pm 0.22 \mathrm{~b}$ & $139.60 \pm 0.78 \mathrm{a}$ & $135.88 \pm 4.30 \mathrm{a}$ & $100.35 \pm 0.20 \mathrm{c}$ \\
\hline Uric acid (mg/dl) & $5.89 \pm 3.00 \mathrm{~b}$ & $6.11 \pm 0.33 \mathrm{~b}$ & $9.01 \pm 0.10 \mathrm{a}$ & $8.79 \pm 0.56 \mathrm{a}$ \\
\hline Glucose $(\mathbf{m g} / \mathbf{d l})$ & $184.12 \pm 3.10 \mathrm{a}$ & $191.019 \pm 2.90 \mathrm{~b}$ & $200.070 \pm 1.43 \mathrm{c}$ & $210.12 \pm 2 . \mathrm{c}$ \\
\hline
\end{tabular}

Values represent Mean \pm S.E.

\section{Different letters in each row mean significant differences $(\mathbf{p} \leq \mathbf{0 . 0 5})$}

In Table (3), the values of total protein were significantly $(\mathrm{P} \leq 0.05)$ advanced as the age of pigeons increase, it is due to the necessity of protein for growth in different ages of birds. These results may be attributed to their greater demand for proteins and amino acid during growth for the immature avian species (Palomeque et al., 1991). It is believed that increasing of total protein may reflect that rate of anabolism was higher than the rate of catabolism in avian bodies. There is increasing in plasma total cholesterol and triglycerides in immature birds compared to the mature, it is due to the energy reserves required for growth and maturation (Palomeque et al., 1991).

The (Kececl and Col, 2011) showed that the increase of cholesterol in juveniles when compared with adult. Uric acid levels of the adult were significantly $(\mathrm{P} \leq 0.05)$ higher than those of the young $(\mathrm{P} \leq 0.05)$, it is may be due to high protein content in the feed.

The plasma glucose in Table (3) offered that the immature pigeons had significantly $(\mathrm{P} \leq 0.05)$ lower plasma glucose values than mature birds. Also, the plasma glucose was rise gradually which mean that the mature birds had significantly $(\mathrm{P} \leq 0.05)$ higher plasma glucose than the immature. The obtained results may reflect that the young pigeons (squabs) are still depend on their parents in the feeding and their activities are lower compared to the adult pigeons that are self feeding, have more activities and look after their offspring and this may be the reason that young pigeons had lower glucose than the adult. 
These results are in agreement with (Ritchie et al., 1994) they discovered that plasma glucose reached the maximum level in mature birds.

\section{CONCLUSIONS}

We can conclude from this study that these findings may be useful as a diagnostic tool in the physiological knowledge of blood at different ages to help the authors in development and production.

\section{REFERENCES}

Chandler, R.F.; Hooper, S.N.; Ismail, H.A. (1979). Antihypercholesterolemic studies with steols: Comparison of rats and chicks as animal model. Can. J. Pharm. Sci., 14, 15-20.

Fransson, T.; Kolehmainen, T.; Kroon, C.; Jansson, L.; Wenninger, T. (2010). EURING List of Longevity Records for European Birds. EURING Bird Ringing Datsbank, www.euring.org/data_ and codes/longevity - voous.htm.

Gayathri, K.L.; Hegde, S.N. (1994). Sexual differences in blood values of the pigeon, Columba livia. Comp. Bioch. Phys., 109B, 219-224.

Grunenberg, R.; Banik, N.; Kruger, J. (1995). Alanine aminotransferase (ALAT,GPT): a reevaluation of exclusion limits for blood donors. Infus. Transfu.med. 22(3), 145-51.

Hames, B.D.; Hooper, N.M. (2002). Global population and the nitrogen cycle. Trends. Biochem. Sci., 29, 407-408.

Harr, K.E. (2002 a). Clinical chemistry of companion avian species: A review. Vet. Clin. Path., 31(3), 140-149.

Harr, K.E. (2002b). Clinical chemistry of companion avian species: A Review. Vet. Clin. Patl., 31, 140151.

Hauptmanova, K.; Literak, I.; Bartova, E. (2002). Hematology and leucocytozoonosis of great tits (parus major L.) during winter. Acta Vet. Brno., 71, 199-204.

Islam, M.S.; Lucky, N.S.; Islam, M.R.; Ahad, A.; Das, B.R.; Rahman, M.M.; Siddiui, M.S.I. (2004). Haematological parameters of fayoumi, assail and local chickens reared in Sylhet region in Bangladesh. Int. J. Poult. Sci., 3, 144-147.

Kasprzak, M.; Hetmanski, T. (2004). Plasma fat parameters in the feral pigeon (Columba livia f. urbana) during its postembryonic development. Zool. Polon., 49, 229-235.

Kececl, K.; Col, R. (2011). Haematological and biochemical values of the blood of Pheasants (Phasianus colchicus) of different ages. Turk. J. Vet. Anim. Sci., 35, 149-156.

Kral, I.; Suchy , P. (2000). Haematological studies in adolescent breeding cocks. Acta. Vet. Bmo., 69, 189-194.

Lashev, L.; Hubenov, H.; Nikolov, Y.; Lasheva, V.; Mihailov, R. (2009). Comparison of some haematological parameters between three bird species from the Columbidae family - short communication. Vet. Arhiv., 79, 409-414.

Miller, M.J.; Wayland, M.E.; Bortolotti, G.R. (2001). Hemograms for and nutritional condition of migrant bald eagles tested for exposure to lead. J. Wildlife Dis. 37, 481-488.

Moudhafer, A.S.; Porter, R.F.; Langman, M.; Christensen, B.; Schiermacker-Hansen, P.; Al- Jebouri, S. (2006). Field Guide to the birds of Iraq. (in Arabic). Nature of Iraq and Bird Life. International Press, Baghdad.

NRC (National Research C ouncil), (1984). Nutrient Requirements of Poultry. $8^{\text {th }}$ Edn., Revised., Washington D.C., pp. 11-15.

Palomeque, J.; Pinto, D.; Viscor, G. (1991). Hematologic and blood chemistry values of the Masai ostrich (Struthio camelus). J. Wildl. Dis., 27, 34-40.

Palvak, M.; Vlahovic, K.; Jercic, J.; Dovc, A.; Zupancic, Z. (2005). Age, sexual and seasonal differences of haematological values and antibody status to Chlamydophila sp. In feral and rasing pigeons (Columba livia forma domestica) from an urban environment (Zagreb, Croatia). Eur. J. Wildlife Res. 51, 271-276. 
Payne, J.M.; Dew, S.M.; Manston, R.; Faulks, M. (1970). The use of a metabolic profile test in dairy herds. Vet. Reo., 87, 150-158.

Rewkiewiccz-Dziarska, A. (1975). Seasonal changes in hemoglobin and erythrocyte indices in Microtus arvalis. Bull Acad Polon Sci., 23, 481-486.

Ritchie, B.W.; Harrison, J.G.; Harrison, R.L. (1994). Avian Medicine, Winger's Publishing, Inc, Florida.

Rivetz, B.; Begin, E.; Hornstein, K.; Nerdinger, M. (1977). Biochemical changes in fowl serum during infection with strains of Newcastle disease virus of different virulence. Changes in serum proteins, uni acid, lipids and electrolytes. Res. Vet. Sci., 22, 285-291.

Schalm, O.W.; Jain, N.C.; Carroll, E.J. (1975). "Veterinary Haematology". $3^{\text {rd }}$ ed. Lea and Febiger, Philadephia. 62, 377, 540-542.

Schmidt, E.M.S.; Paulillo, A.C.; Dittrich, R.L.; Santin, E.; da Silva, P.C.L.; Beltrame, O.; de Oliveira (2007). The effect of age on hematolgical and serum biochemical values on juvenile ring-necked pheasants (Phasianus colchicus). Int. J. Poult. Sci., 6, 459-461.

Seiser, P.E.; Duffy, L.K.; McGuire, A.D.; Roby, D.D.; Golet, G.H.; Ltizow, M.A. (2000). Comparison of pigeon guillemot: Blood parameters from oiled and onoiled areas of Alaska eight years after the Exxon Valdez oil spill. Mar. Bull., 40, 152-164.

Shen, P.F.; Patterson, L.T. (1983). A simplified Wright's stain technique for routine avian blood smear staining. Poultry Sci., 62, 923-924.

Steel, R.G.D; Torrie, J.H. (1980). Principles and procedures of statistics. $2^{\text {nd }}$ ed., Mcgraw-Hill book Co. Inc. New York. USA.

Tras, B.; Inal, F.; Bas, A.L.; Altunok, V.; Elmas, M.; Yazar, E. (2000). Effects of continuous supplementation on ascorbic acid, aspirin, vitamin $\mathrm{E}$ and selenium on some haematological parameters and serum superoxide dismustase level in broiler chickens. Br. Poult. Sci., 41, 664666. 